\title{
Note on a Hermaphrodite Cod (Gadus morrhua).
}

\author{
By \\ A. E. Hefford, B.Sc., \\ Assistant Naturalist at the Plymouth Laboratory. \\ With one Figure in the Text.
}

ON February 27th, the roe of a cod having a testicular portion attached was received at the Laboratory from Messrs. Moodys and Kelly, of Grimsby. It had been taken from a cod caught by a steam trawler fishing in Icelandic waters. Owing to the rough removal of the organs from the fish on the trawling ground, the genital ducts were missing and the region of their origin was ruptured, while the testis had been somewhat damaged in the course of its long journey to Plymouth.

Fig. 1 shows a drawing of the organs seen from the ventral side. The female element predominates, the ovaries appearing quite normal and functional, with unripe ova at a stage of development which suggests that spawning should occur in about two to four months. The left ovary is $6 \frac{1}{2}$ inches long and the right one $6 \frac{1}{4}$ inches-a practically symmetrical condition. The testicular portion is connected with the left ovary by a duct a quarter to half an inch long, enclosed by a continuation of the fibrous covering of the ovary, the point of connection being very near to the median line and about a quarter of an inch behind the anterior extremity of the median ovarian mass. The form of the testis is rather rosette-like and frilled, but much less lobulated than a normal testis. The length of the longest lobe of the rosette measured from the duct is about 3 inches. It is now rather broken, however, and the original length was probably a little greater.

Internally the testis duct is longitudinally ridged, one of these ridges widening into a valve-like flap near the small aperture which leads into the lumen of the ovary. The testis is in a well-developed but unripe condition. Owing to maceration in the course of transiton the trawler it was kept in ice and then sent through the post to- 
Plymouth wrapped up in paper in a box-the tissue is not suitable for microscopic examination. It is probable, however, that the male organ would be functional, and that when ripe its products would pass to the exterior via the testis duct and the ovary. Owing to the ruptured condition of the right ovary in the region corresponding to the testis

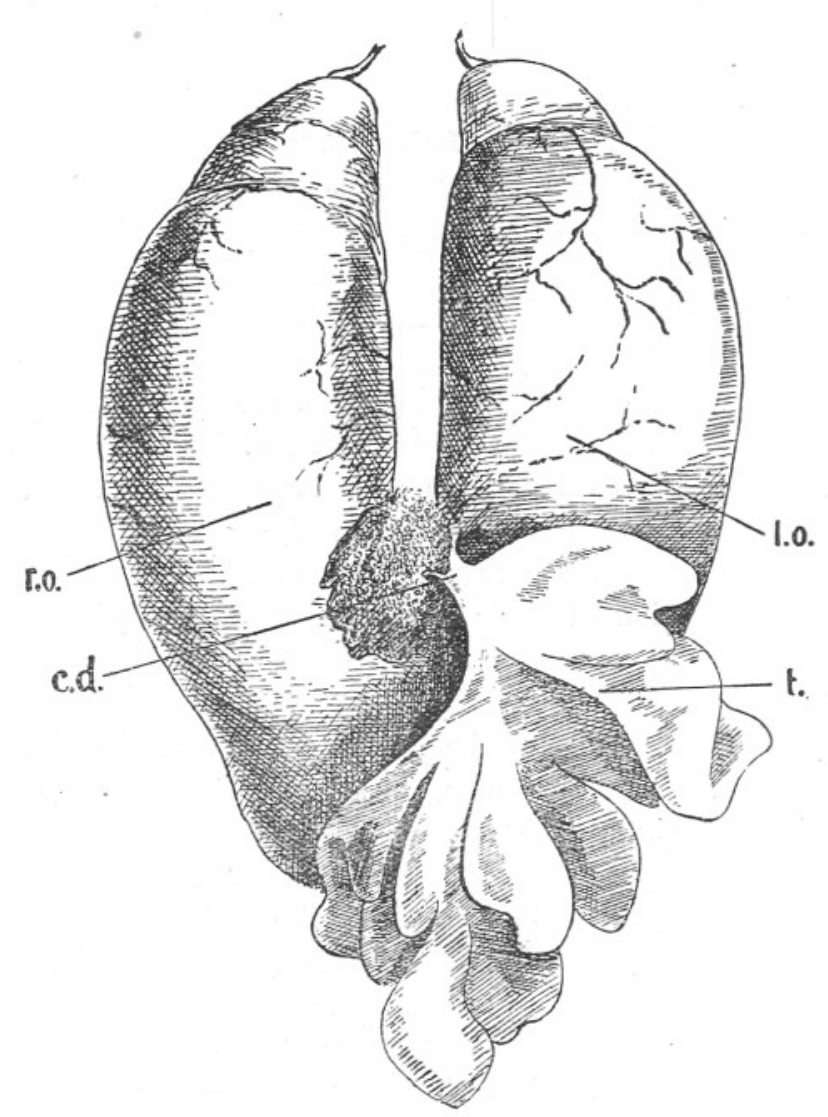

Fig. 1.-Hermaphrodite Gonad of Cod.

r.o., right ovary ; l.c., left ovary ; t., testis ; c.d., testis duct.

duct attachment on the left, I am not able to say with absolute certainty that the above-mentioned is the only testicular part, though there is extremely little doubt but that the whole of the genitalia were removed from the fish, the ruptured portion being the result of tearing away the roe from its duct to the exterior. 
Other examples of hermaphroditism in cod have been described by Howes, ${ }^{*}$ Masterman, $\uparrow$ Williamson, $\ddagger$ etc.

Masterman gives a tabular list of eleven cases for comparison, including his own observation and those cited by Howes. In all these the ovarian organ preponderates. Great diversity is shown in the position of the testis, which may be single or in as many as three distinct and separately attached parts. In Williamson's two cases, one presents a perfectly symmetrical form with a small testis attached to the anterior end of each ovary, while the other is completely asymmetrical, the right gonad being an ovary and the left a testis, the two uniting in the anal region and having a common genital aperture. My specimen presents a further variation in the position of the testis. In the relatively large size of the testicular portion it is also peculiar.

* G. B. Howes, "Hermaphrodite Genitalia of the Codfish," etc. (Journ. Linn. Soc., xxiii., p. 539).

† Masterman, "On Hermaphroditism in the Cod" (Thirteenth Annual Report of the Fishery Board for Scotland, Part III, for the year 1894, p. 297).

\$ Williamson, "On Two Cases of Hermaphroditism in the Cod" (Twenty-fourth Annual Report of the Fishery Board for Scotland, Part III, for the year 1905, p. 290). 